\title{
Evaluation of various real-time RT-PCR assays for the detection and quantitation of human norovirus
}

\author{
Sophie Butot ${ }^{\mathrm{a}}$, Francoise S. Le Guyader ${ }^{\mathrm{b}}$, Joanna Krol ${ }^{\mathrm{b}}$, Thierry Putallaz ${ }^{\mathrm{a}}$, Richard Amoroso ${ }^{\mathrm{a}}$ and \\ Gloria Sánchez ${ }^{a, *}$
}

\author{
${ }^{a}$ Quality \& Safety Assurance Department, Nestlé Research Center, Vers-chez-les-Blanc, CH-1000 Lausanne 26, \\ Switzerland \\ b IFREMER, Laboratoire de Microbiologie, 44311 Nantes Cedex 03, France \\ *: Corresponding author : Gloria Sánchez, Tel.: +34 9639000 22; fax: +34 9636363 01, email address : \\ gloriasanchez@iata.csic.es
}

\begin{abstract}
:
Human noroviruses (NoVs) are the most common viruses causing acute gastroenteritis in humans. Performance characteristics of two commercial quantitative NoV RT-PCR assays, the Norovirus realtime RT-PCR Kit (AnDiaTec) and the Type I and Type II kits (Generon), and the international assay as selected by the CEN/TC/WG6/TAG4 group were evaluated for the specific detection and quantitation of $59 \mathrm{NoV}$ samples, including different subtypes of NoV genogroup I and II. The results showed that the method proposed by the CEN/TC/WG6/TAG4 group was 100\% specific since it was able to detect all samples tested. The commercialized kits evaluated failed to detect a vast majority of NoV GI strains. Additionally the Generon kit did not succeed to detect strains from GII.3, GII.5, GII.6, GII.7, GII.8, GII.12 and GII.17. In addition, the detection limit using the most prevalent strain, NoV GII.4, was 2.5 PCRU per reaction using both commercial kits. Despite this good sensitivity for NoV GIl.4 detection it is concluded that both commercial assays are not suitable for the detection and quantitation of most NoV subtypes. Therefore the method proposed by the CEN/TC/WG6/TAG4 group is recommended for epidemiological studies and outbreaks investigations.
\end{abstract}

Keywords: Norovirus; Real-time RT-PCR; Commercial kit 


\section{Introduction}

Noroviruses (NoVs) are the most common viruses causing acute gastroenteritis in humans and also the leading cause of foodborne illness in developed countries (Anonymous 2006; Anonymous 2009; Zheng et al., 2006). NoVs are non-enveloped viruses with a single-stranded, positive-sense RNA genome and they are classified within the Caliciviridae family. NoVs are diverse genetically and antigenically and genetic analysis is the main method to classify NoV strains. So far, and based on the complete capsid gene sequences, NoVs have been classified into five genogroups (G) and a number of unclassified strains (Glass et al., 2009). Of them, GI, GII and GIV strains are infectious to humans and strains of genogroup II, more precisely GII.4, are the leading cause of NoV infections.

Although attempts to culture human NoVs have been made (Guix et al., 2007; Straub et al., 2007), there is no reliable culture method (Duizer et al., 2004). As a result, RT-PCR or real-time RT-PCR (RT-qPCR) is considered to be the "gold standard" for detection of NoVs in clinical, food and environmental samples. To date, several RTqPCR assays have been described for NoV detection (da Silva et al., 2007; Dreier et al., 2006; Jothikumar et al., 2005; Kageyama et al., 2003; Loisy et al., 2005). In addition, a real-time RT-PCR method, referred to as method A, is being assessed in the framework of the CEN/TC275/WG6/TAG4 group (Le Guyader et al., 2009). This group has been entrusted by the European Committee for Standardization to establish a method for detecting norovirus and hepatitis A virus in foods and bottled water (http://www.cen.eu/cenorm/sectors/sectors/isss/index.asp).

Due to the high impact of NoV outbreaks, several companies have developed kits for the detection and quantitation of NoV (e.g. Alpco Diagnostics, AnDiaTec, ifp Institut für Produktqualität, Shanghai Zhijiang Biotechnology Co., Generon, Eiken Chemical Company, CEERAMTools, SAS). Among them, the Norovirus real-time RT-PCR Kit (AnDiaTec GmbH \& Co. KG, Kornwestheim, Germany) and the Norovirus Type I and 
1 II kits (Generon S.r.l., Castelnuovo, Italy) have been evaluated in this study using a

2 panel of different NoVs strains. In addition, the results were compared with those

3 obtained using the method proposed in the framework of the CEN/TC275/WG6/TAG4

4 group (Le Guyader et al., 2009).

5 2. Materials and methods

6 2.1. Clinical samples and reference panel

8 fecal positive samples for human NoV kindly provided by the by the Dutch National

9 Institute for Public Health and the Environment (RIVM; Dr. Koopmans, Bilthoven, The 10 Netherlands), Dr. Buesa (University of Valencia, Spain) or strains characterized 11 previously (Lamothe et al., 2003). In addition an RNA NoV reference panel was used in 12 this study. This panel was set up by the Dutch National Institute for Public Health and 13 the Environment (Bilthoven, the Netherlands) and consisted of RNA fragments 14 synthesized in vitro of nine NoV GI and nine NoV GII strains.

\subsection{Viral RNA extraction}

Viral RNA was extracted from $140 \mu 1$ of fecal samples $(10 \%$ diluted in PBS) by using the QIAamp viral RNA (Qiagen, Hilden, Germany), according to the manufacturer's instructions. RNA extracts were either immediately analyzed by RTqPCR or stored at $-80^{\circ} \mathrm{C}$ until use.

\subsection{NoV real-time RT-PCR assays}

In order to be able to compare data, all tests were conducted using the same apparatus, the LightCycler 2.0 instrument (Roche Diagnostics, Mannheim, Germany). For all assays, five $\mu 1$ of RNA were transferred to a LightCycler capillary tube containing $15 \mu l$ of the RT-qPCR mix.

\subsubsection{Method A}

Primers targeted the ORF2 region; for NV GI: forward primer QNIF4 (5'-

27 CGCTGGATGCGNTTCCAT-3' where $\mathrm{N}$ is $\mathrm{A}, \mathrm{C}, \mathrm{G}$, or T), reverse primer NV1LCR 
(5'-CCTTAGACGCCATCATCATTTAC-3') and probe NV1LCpr (6-

2 carboxyfluorescein-TGGACAGGAGAYCGCRATCT-6-carboxytetramethylrhodamine

3 where $\mathrm{Y}$ is $\mathrm{C}$ or $\mathrm{T}$ and $\mathrm{R}$ is $\mathrm{A}$ or $\mathrm{G}$ ) were employed; for GII, forward primer QNIF2d

4 (5'AtGTtCAGRTGGATGAGRTTCTCWGA-3' where $\mathrm{R}$ is A or G and $\mathrm{W}$ is A or T),

5 reverse primer COG2R (5'-TCGACGCCATCTTCATTCACA-3'), and probe QNIFS (6-

6 carboxyfluorescein-AGCACGTGGGAGGGGATCG-6-carboxytetramethylrhodamine)

7 were used (da Silva et al., 2007; Le Guyader et al., 2009).

8 The RT-qPCR was carried out using the Platinum ${ }^{\circledR}$ Quantitative RT-PCR

9 ThermoScript ${ }^{\mathrm{TM}}$ One-Step kit (Invitrogen AG, Basel, Switzerland). Final concentrations were $250 \mathrm{nM}$ probe, $500 \mathrm{nM}$ forward primer, $900 \mathrm{nM}$ reverse primer, $0.5 \mu \mathrm{M}$ Rox reference dye, $0.4 \mu 1$ of a ThermoScript Plus/Platinum Taq enzyme mixture, and $3.2 \mathrm{U}$ of RNase inhibitor (Promega, Madison, USA). RT was performed for 60 min at $55^{\circ} \mathrm{C}$. Amplification was performed for $5 \mathrm{~min}$ at $95^{\circ} \mathrm{C}$, and 45 cycles of $95^{\circ} \mathrm{C}$ for $15 \mathrm{~s}, 60^{\circ} \mathrm{C}$ for $1 \mathrm{~min}$ and $65^{\circ} \mathrm{C}$ for $1 \mathrm{~min}$.

\subsubsection{Method B: Generon assay}

The RT-qPCR was conducted using the Platinum ${ }^{\circledR}$ Quantitative RT-PCR ThermoScript ${ }^{\mathrm{TM}}$ One-Step System (Invitrogen) using the specific primers and probes supplied by the norovirus Type I and Type II kits (Generon, Castelnuovo Rangone, Italy) following the instructions given by the manufacturer, with the exception that the final volume was adjusted from 50 to $20 \mu \mathrm{l}$. RT was performed at $48^{\circ} \mathrm{C}$ for $30 \mathrm{~min}$; after denaturation at $95^{\circ} \mathrm{C}$ for 10 min amplification was performed by 45 cycles of $95^{\circ} \mathrm{C}$ for $15 \mathrm{~s}$ and $60^{\circ} \mathrm{C}$ for $1 \mathrm{~min}$.

\subsubsection{Method C: AnDiaTec assay}

The AnDiaTec norovirus real-time RT-PCR kit (AnDiaTec GmbH \& Co. KG, Kornwestheim, Germany) contains specific primers, Taqman probes and additional material for the simultaneous detection of human NoVs GI and GII. Real-time quantitative amplification of NoV RNA was undertaken according to the instructions 
1 given by the manufacturer: RT was performed at $45^{\circ} \mathrm{C}$ for $30 \mathrm{~min}$; after denaturation at

$295^{\circ} \mathrm{C}$ for $2 \mathrm{~min}$ amplification was performed by 45 cycles of $95^{\circ} \mathrm{C}$ for $0 \mathrm{~s}, 50^{\circ} \mathrm{C}$ for $30 \mathrm{~s}$

3 and $72^{\circ} \mathrm{C}$ for $15 \mathrm{~s}$, with a terminal cycle of $40^{\circ} \mathrm{C}$ for $30 \mathrm{~s}$.

\section{$4 \quad$ 2.4. Detection limit}

$5 \quad$ NoV stocks titrated previously (Butot et al., 2007) as $1.2 \times 10^{9}$ PCRU/ml for NoV

6 GI.4 and $2.0 \times 10^{9} \mathrm{PCRU} / \mathrm{ml}$ for NoV GII.4 were used to determine the detection limit of 7 each assay. Serial dilutions of viral RNA $\left(10^{-3}\right.$ to $\left.10^{-8}\right)$ were assayed by each RT-qPCR

8 method as described above. Exceptionally, Method A was evaluated also using different

9 RT-qPCR kits; the Platinum ${ }^{\circledR}$ Quantitative RT-PCR ThermoScript ${ }^{\mathrm{TM}}$ One-Step System and the RNA UltraSense One-Step Quantitative RT-PCR System, both from Invitrogen and the AgPath One-Step RT-PCR Kit from Ambion.

\section{Results}

\subsection{Specificity of the assays for NoV GI}

The specificity of the assays was analyzed using nine RNA fragments and nine faecal samples covering nine different genotypes. Method A was able to detect all tested samples (18/18) (Table 1). Concerning methods B and C, both kits detected the Norwalk strain (GI.1) but failed for the detection of most other strains. Method B and C only detected $16.6 \%(3 / 18)$ and $11.1 \%(2 / 18)$ of the strains evaluated (Table 1$)$.

\subsection{Specificity of the assays for NoV GII}

Method A was able to detect $100 \%$ (41/41) of all NoV GII samples tested whilst Method B and C detected 63.4\% (26/41) and 97.5\% (40/41) of the strains evaluated. The Method C missed the GII.2 strains detection, since the assay only detected one of the sample which contained a large number of RNA copies based on CP values obtained with Method A. Performance of Method B was comparatively worse than the other two methods since it only detected strains of GII.1, GII.2, GII.4, GII.10 and GIIb (Table 2).

\subsection{Detection limit of NoV GI and GII assays}


Due to the poor performance of the commercial kits evaluated (Method B and C) for

2 detecting NoV GI strains, limit of detection for NoV GI was only established with the

3 Method A. Additionally, Method A was evaluated using various RT-qPCR kits; results

4 showed that the three kits yielded similar results in terms of detection values. Positive

5 amplification in all replicates of each RNA dilution was achieved when 16.8 or more

6 PCRU were present, and as few as 1.7 PCRU could be detected with 50 and 33\%

7 probability when using the UltraSense and Platinum kits (Table 3).

8 Regarding the NoV GII assays, Method A (Platinum kit) and Method B detected as

9 few as 0.25 PCRU of NoV GII.4 with 20\% and $80 \%$ probability, respectively. Whereas

Method C showed positive amplification in all replicates when 2.5 PCRU were present

11 (Table 4).

\section{Discussion}

In view of the increasing number of norovirus outbreaks it has become even more important to have reliable and widely applicable techniques for the detection and quantitation of human NoV. This fact is reflected by the attention that biotechnology companies give to develop new assays for NoV GI and GII detection. This work presents an evaluation of two commercial RT-qPCR assays for the detection and quantitation of human norovirus. The performance of the assays was compared to a well established method proposed by the CEN/TC275/WG6/TAG4 group (Le Guyader et al., 2009).

Overall, the two commercial assays, Generon and AnDiaTec, failed to detect most of the NoV GI strains tested. The Generon assay most likely contains primers for NoV GI detection based on Norwalk strain since CP values were even better than those obtained with the method proposed by the CEN group. Problems detecting specific NoV strains is a common issue, for instance another commercial assay, the Loopamp assay failed to detect all NoV GI.3 strains tested and one out of five NoV GII.3 strains (Iturriza-

27 Gomara et al., 2008). In addition, a multilaboratory study showed that the sensitivity of 
1 RT-qPCR assays to detect NoV GI was lower than those detecting NoV GII (Made et

2 al., 2006). This is especially relevant since several authors have reported an unexpected

3 high prevalence of NoV GI in the environment (da Silva et al., 2007; Jothikumar et al.,

4 2005; Le Guyader et al., 2009; Nishida et al., 2007) considering that most of strains

5 circulating in humans belong to GII, with GII.4 the predominant group. It has been

6 hypothesized that NoV GI is more prevalent in the environment due to its greater

7 resistance to inactivation (Butot et al., 2009; da Silva et al., 2007).

8 Sensitivity of RT-qPCR assays is a crucial issue, especially when working with

9 environmental and food samples. These types of samples are highly demanding due to the minimal infectious dose reported for NoV and the low concentration of human NoV found in food samples. So far, only naturally contaminated shellfish samples have been quantified, ranging from $10^{2}$ to $10^{4}$ copies per g of digestive tissues (Le Guyader et al., 2006; Le Guyader et al., 2009; Nishida et al., 2007). According with our results, the two commercial kits evaluated showed a good sensitivity for detecting NoV GII.4 in a low copy numbers (i.e. 2.5 PCRU per reaction) as well as the assay proposed by the CEN method.

Based on these results it is concluded that both commercial kits are only suitable for the detection and quantitation of most NoV GII strains frequently isolated, the NoV GII.4. Currently, the strains most prevalent circulating belong to genogroup II.4, responsible for up to $80 \%$ of NoV outbreaks (Siebenga et al., 2007). However a more specific method, such as the method proposed by the CEN group, is recommended in order to have a real picture of circulating NoV strains. In addition, Stals and coauthors (Stals et al., 2009) have recently adapted this assay into a two-step multiplex RT-qPCR, which will reduce certainly the cost of the assay.

\section{Acknowledgements}

The norovirus RNA reference panel was provided kindly by Marion Koopmans and Dr. Erwin Duizer of the National Institute for Public Health and the Environment 
1 (Bilthoven, the Netherlands). This study was supported in part by the DGAL (Direction 2 Generale de l'Alimentation, French Ministry of Health and Food). 


\section{References}

Anonymous, 2006. Annual Listing of Foodborne Disease Outbreaks, United States. CDC.

Anonymous, 2009. The Community Summary Report on Food-borne Outbreaks in the European Union in 2007. EFSA J. 271.

Butot, S., Putallaz, T., Amoroso, R., Sanchez, G., 2009. Inactivation of Enteric Viruses in Minimally Processed Berries and Herbs. Appl. Environ. Microbiol. 75, 4155-4161.

Butot, S., Putallaz, T., Sanchez,G., 2007. Procedure for rapid concentration and detection of enteric viruses from berries and vegetables. Appl. Environ. Microbiol. 73, 186-192.

da Silva, A.K., Le Saux, J.C., Parnaudeau, S., Pommepuy, M., Elimelech,M., Le Guyader, F.S., 2007. Removal of norovirus in wastewater treatment using real-time RT-PCR: different behavior of genogroup I and genogroup II. Appl. Environ. Microbiol. 73, 7891-7897.

Dreier, J., Stormer, M., Made, D., Burkhardt, S., Kleesiek, K., 2006. Enhanced reverse transcription-PCR assay for detection of norovirus genogroup I. J. Clin. Microbiol. 44, 2714-2720.

Duizer, E., Schwab, K.J., Neill, F.N., Atmar, R.L., Koopmans, M.P.G., Estes, M.K., 2004. Laboratory efforts to cultivate noroviruses. J. Gen. Virol. 85, 79-87.

Glass, R.I., Parashar, U.D., Estes, M.K., 2009. Norovirus gastroenteritis. N. Engl. J. Med. 361, $1776-1785$.

Guix, S., Asanaka, M., Katayama, K., Crawford, S.E., Neill, F.H., Atmar, R.L., Estes, M.K., 2007. Norwalk Virus RNA is infectious in mammalian cells. J. Virol. 81, 12238-12248.

Iturriza-Gomara, M., Xerry, J., Gallimore, C.I., Dockery, C., Gray, J., 2008. Evaluation of the Loopamp (loop-mediated isothermal amplification) kit for detecting Norovirus RNA in faecal samples. J. Clin. Virol. 42, 389-393. 
1 Jothikumar, N., Lowther, J.A., Henshilwood, K., Lees, D.N., Hill, V.R., Vinje, J., 2005. Rapid and Sensitive Detection of Noroviruses by Using TaqMan-Based One-Step Reverse Transcription-PCR Assays and Application to Naturally Contaminated Shellfish Samples. Appl. Environ. Microbiol. 71, 1870-1875.

5 Kageyama, T., Kojima, S., Shinohara, M., Uchida, K., Fukushi, S., Hoshino, F.B., Takeda, N., Katayama, K., 2003. Broadly reactive and highly sensitive assay for Norwalk-like viruses based on real-time quantitative reverse transcription-PCR. J. Clin. Microbiol. 41, 15481557.

Lamothe, G.T., Putallaz, T., Joosten, H., Marugg, J.D., 2003. Reverse transcription-PCR analysis of bottled and natural mineral waters for the presence of noroviruses. Appl. Environ. Microbiol. 69, 6541-6549.

Le Guyader, F.S., Bon, F., DeMedici, D., Parnaudeau, S., Bertone, A., Crudeli, S., Doyle, A., Zidane, M., Suffredini, E., Kohli, E., Maddalo, F., Monini, M., Gallay, A., Pommepuy, M., Pothier, P., Ruggeri, F.M., 2006. Detection of multiple noroviruses associated with an international gastroenteritis outbreak linked to oyster consumption. J. Clin. Microbiol. 44, $3878-3882$.

Le Guyader, F.S., Parnaudeau, S., Schaeffer, J., Bosch, A., Loisy, F., Pommepuy, M., Atmar, R.L., 2009. Detection and quantification of noroviruses in shellfish. Appl. Environ. Microbiol. 75, 618-624.

Loisy, F., Atmar, R.L., Guillon, P., Le Cann, P., Pommepuy, M., Le Guyader, F.S., 2005. Realtime RT-PCR for norovirus screening in shellfish. J. Virol. Methods 123, 1-7.

Made, D., Reiting, R., Dreier, J., Heun-Munch, B., Loos, U., Hagen, M., Burkhardt, S., Schrader, C., Becker, B., 2006. Detection of norovirus in environmental samples. Results of a ring trial for method development. Arch.Lebensmittelhyg. 57, 29-35. 
1 Nishida, T., Nishio, O., Kato, M., Chuma, T., Kato, H., Iwata, H., Kimura, H., 2007. Genotyping and quantitation of noroviruses in oysters from two distinct sea areas in Japan. Microbiol.Immunol. 51, 177-184.

4 Siebenga, J.J., Vennema, H., Renckens, B., de Bruin, E., van der Veer, B., Siezen, R.J., Koopmans, M. (2007) Epochal evolution of GGII.4 norovirus capsid proteins from 1995 to 2006. J. Virol. 81, 9932-9941.

Stals, A., Baert, L., Botteldoorn, N., Werbrouck, H., Herman, L., Uyttendaele, M., Van, C.E., 2009. Multiplex real-time RT-PCR for simultaneous detection of GI/GII noroviruses and murine norovirus 1. J. Virol. Methods 161, 247-253.

10

Straub, T.M., Honer zu, B.K., Orosz-Coghlan, P., Dohnalkova, A., Mayer, B.K., Bartholomew, R.A., Valdez, C.O., Bruckner-Lea, C.J., Gerba, C.P., Abbaszadegan, M., Nickerson, C.A., 2007. In vitro cell culture infectivity assay for human noroviruses. Emerg. Infect. Dis. 13, 396-403.

Zheng, D.P., Ando, T., Fankhauser, R.L., Beard, R.S., Glass, R.I., Monroe, S.S., 2006. Norovirus classification and proposed strain nomenclature. Virol. 346, 312-323. 
1 Table 1. Specificity of assays for the detection of NoV genogroup I using the

2 LightCycler 2.0

\begin{tabular}{|c|c|c|c|c|c|c|c|c|c|c|}
\hline \multirow[t]{2}{*}{ Genotype } & \multirow[t]{2}{*}{ Prototype } & \multicolumn{3}{|c|}{ Method A (CEN) } & \multicolumn{3}{|c|}{$\begin{array}{l}\text { Method B } \\
\text { (Generon assay) }\end{array}$} & \multicolumn{3}{|c|}{$\begin{array}{l}\text { Method C } \\
\text { (AnDiaTec assay) }\end{array}$} \\
\hline & & $+/ \mathrm{n}^{\mathrm{a}}$ & Mean CP & SD & $+/ \mathrm{n}^{\mathrm{a}}$ & Mean CP & SD & $+/ \mathrm{n}^{\mathrm{a}}$ & Mean CP & SD \\
\hline \multirow[t]{2}{*}{ GI.1 } & Aichi & $2 / 2$ & 22.17 & 0.08 & $0 / 2$ & - & - & $0 / 2$ & - & - \\
\hline & $\underline{\text { Norwalk }}$ & $2 / 2$ & 22.61 & 0.01 & $2 / 2$ & 14.49 & 0.33 & $2 / 2$ & 34.41 & 0.22 \\
\hline \multirow[t]{4}{*}{ GI.2 } & Southampton & $2 / 2$ & 26.44 & 0.29 & $0 / 2$ & - & - & $0 / 2$ & - & - \\
\hline & $\underline{\text { Southampton }}$ & $2 / 2$ & 10.60 & 0.45 & $2 / 2$ & 39.01 & 1.4 & $0 / 2$ & - & - \\
\hline & Whiterose & $2 / 2$ & 22.31 & 0.81 & $0 / 2$ & - & - & $0 / 2$ & - & - \\
\hline & $\underline{\text { Whiterose }}$ & $2 / 2$ & 12.86 & 2.36 & $2 / 2$ & $>40.0$ & - & $0 / 2$ & - & - \\
\hline GI.3 & Birmingham & $2 / 2$ & 11.66 & 1.35 & $0 / 2$ & - & - & $0 / 2$ & - & - \\
\hline \multirow[t]{3}{*}{ GI.4 } & Queens Arms & $2 / 2$ & 27.04 & 0.16 & $0 / 2$ & - & - & $0 / 2$ & - & - \\
\hline & Queens Arms & $2 / 2$ & 23.18 & 0.08 & $0 / 2$ & - & - & $2 / 2$ & 38.76 & 1.75 \\
\hline & $\underline{\text { Malta }}$ & $2 / 2$ & 9.01 & 0.07 & $0 / 2$ & - & - & $0 / 2$ & - & - \\
\hline GI.5 & Musgrove & $2 / 2$ & 30.29 & 0.55 & $0 / 2$ & - & - & $0 / 2$ & - & - \\
\hline \multirow[t]{2}{*}{ GI.6 } & ND & $2 / 2$ & 28.49 & 0.41 & $0 / 2$ & - & - & $0 / 2$ & - & - \\
\hline & Mikkeli & $2 / 2$ & 18.13 & 0.04 & $0 / 2$ & - & - & $0 / 2$ & - & - \\
\hline \multirow[t]{2}{*}{ GI.7 } & ND & $2 / 2$ & 22.59 & 0.87 & $0 / 2$ & - & - & $0 / 2$ & - & - \\
\hline & $\underline{\mathrm{ND}}$ & $2 / 2$ & 8.56 & 0.81 & $0 / 2$ & - & - & $0 / 2$ & - & - \\
\hline GI.9 & ND & $2 / 2$ & 24.54 & 0.66 & $0 / 2$ & - & - & $0 / 2$ & - & - \\
\hline GI.10 & $\underline{\text { Boxer }}$ & $2 / 2$ & 10.68 & 0.14 & $0 / 2$ & - & - & $0 / 2$ & - & - \\
\hline GI? & ND & $2 / 2$ & 22.84 & 0.39 & $0 / 2$ & - & - & $0 / 2$ & - & - \\
\hline
\end{tabular}

5 Underlined: RNA fragments 
Table 2. Specificity of assays for the detection of NoV genogroup II using the LightCycler 2.0

\begin{tabular}{|c|c|c|c|c|c|c|c|c|c|c|}
\hline \multirow[t]{2}{*}{ Genotype } & \multirow[t]{2}{*}{ Prototype } & \multicolumn{3}{|c|}{ Method A (CEN) } & \multicolumn{3}{|c|}{$\begin{array}{c}\text { Method B } \\
\text { (Generon assay) }\end{array}$} & \multicolumn{3}{|c|}{ Method C } \\
\hline & & $+/ \mathrm{n}^{\mathrm{a}}$ & Mean CP & SD & $+/ \mathrm{n}^{\mathrm{a}}$ & Mean CP & SD & $+/ \mathrm{n}^{\mathrm{a}}$ & Mean CP & SD \\
\hline \multirow[t]{7}{*}{ GII.1 } & Girlington & $2 / 2$ & 22.96 & 0.01 & $2 / 2$ & 31.54 & 0.02 & $2 / 2$ & 23.09 & 0.08 \\
\hline & Girlington & $2 / 2$ & 30.05 & 0.09 & $1 / 2$ & 37.19 & - & $2 / 2$ & 30.63 & 0.08 \\
\hline & Hawaii & $2 / 2$ & 27.46 & 0.53 & $2 / 2$ & 34.2 & 1.42 & $2 / 2$ & 27.99 & 0.37 \\
\hline & Hawaii & $2 / 2$ & 21.77 & 0.05 & $2 / 2$ & 31.72 & 0.47 & $2 / 2$ & 27.31 & 0.36 \\
\hline & Hawaii & $2 / 2$ & 25.95 & 0.05 & $2 / 2$ & 35.76 & 0.56 & $2 / 2$ & 31.12 & 0.23 \\
\hline & Hawaii & $2 / 2$ & 19.02 & 0.05 & $2 / 2$ & 19.03 & 0.15 & $2 / 2$ & 18.90 & 0.00 \\
\hline & $\underline{\text { Hawaii }}$ & $2 / 2$ & 8.08 & 0.07 & $2 / 2$ & 32.95 & 0.22 & $2 / 2$ & 10.05 & 0.08 \\
\hline \multirow[t]{2}{*}{ GII.2 } & Melksham & $2 / 2$ & 26.58 & 0.04 & $2 / 2$ & 29.3 & 0.07 & $0 / 2$ & - & - \\
\hline & Melksham & $2 / 2$ & 8.48 & 0.03 & $2 / 2$ & 25.33 & 0.81 & $2 / 2$ & 32.88 & 0.37 \\
\hline \multirow[t]{2}{*}{ GII.3 } & Towson & $2 / 2$ & 17.19 & 0.05 & $0 / 2$ & - & - & $2 / 2$ & 19.78 & 0.04 \\
\hline & $\underline{\text { Toronto }}$ & $2 / 2$ & 9.98 & 0.03 & $0 / 2$ & - & - & $2 / 2$ & 35.57 & 5.10 \\
\hline \multirow[t]{10}{*}{ GII.4 } & Grimsby & $2 / 2$ & 35.01 & 0.62 & $2 / 2$ & 35.34 & 0.37 & $2 / 2$ & 35.34 & 0.22 \\
\hline & Grimsby & $2 / 2$ & 20.34 & 0.18 & $2 / 2$ & 19.29 & 0.09 & $2 / 2$ & 19.42 & 0.67 \\
\hline & Grimsby & $2 / 2$ & 23.49 & 0.24 & $2 / 2$ & 22.23 & 0.44 & $2 / 2$ & 24.56 & 0.09 \\
\hline & Grimsby & $2 / 2$ & 27.55 & 0.03 & $2 / 2$ & 27.71 & 0.06 & $2 / 2$ & 27.54 & 0.05 \\
\hline & Grimsby & $2 / 2$ & 18.77 & 0.07 & $2 / 2$ & 18.87 & 0.15 & $2 / 2$ & 18.64 & 0.05 \\
\hline & Grimsby & $2 / 2$ & 26.19 & 0.02 & $2 / 2$ & 26.3 & 0.01 & $2 / 2$ & 25.91 & 0.12 \\
\hline & Grimsby & $2 / 2$ & 8.13 & 0.05 & $2 / 2$ & 29.65 & 0.20 & $2 / 2$ & 9.66 & 0.02 \\
\hline & Lorsdale & $2 / 2$ & 31.44 & 0.77 & $2 / 2$ & 23.29 & 0.38 & $2 / 2$ & 24.32 & 0.17 \\
\hline & Lorsdale & $2 / 2$ & 17.53 & 0.23 & $2 / 2$ & 17.04 & 0.01 & $2 / 2$ & 17.36 & 0.52 \\
\hline & Lorsdale & $2 / 2$ & 18.12 & 0.04 & $2 / 2$ & 22.73 & 0.22 & $2 / 2$ & 20.26 & 0.03 \\
\hline
\end{tabular}




\begin{tabular}{|c|c|c|c|c|c|c|c|c|c|c|}
\hline & Lorsdale & $2 / 2$ & 20.84 & 0.04 & $2 / 2$ & 22.85 & 0.17 & $2 / 2$ & 22.53 & 0.07 \\
\hline & Lorsdale & $2 / 2$ & 23.95 & 0.14 & $2 / 2$ & 25.1 & 0.02 & $2 / 2$ & 23.96 & 0.03 \\
\hline & Lorsdale & $2 / 2$ & 19.78 & 0.08 & $2 / 2$ & 20.38 & 0.03 & $2 / 2$ & 20.12 & 0.07 \\
\hline & Burwash Landing & $2 / 2$ & 24.74 & 0.01 & $2 / 2$ & 25.73 & 0.00 & $2 / 2$ & 26.02 & 0.01 \\
\hline & Burwash Landing & $2 / 2$ & 23.17 & 0.04 & $2 / 2$ & 22.94 & 0.02 & $2 / 2$ & 22.51 & 0.05 \\
\hline & Hillingdon & $2 / 2$ & 31.52 & 0.25 & $0 / 2$ & - & - & $2 / 2$ & 32.42 & 0.28 \\
\hline GII.5 & & & & & & & & & & \\
\hline & Hillingdon & $2 / 2$ & 25.42 & 0.15 & $0 / 2$ & - & - & $2 / 2$ & 26.01 & 0.2 \\
\hline & Hillingdon & $2 / 2$ & 21.49 & 0.45 & $0 / 2$ & - & - & $2 / 2$ & 24.05 & 0.26 \\
\hline GII.6 & Saitama & $2 / 2$ & 27.78 & 0.17 & $0 / 2$ & - & - & $2 / 2$ & 32.27 & 0.44 \\
\hline & $\underline{\text { Seacroft }}$ & $2 / 2$ & 9.90 & 0.04 & $0 / 2$ & - & - & $2 / 2$ & 22.61 & 0.45 \\
\hline GII.7 & $\underline{\text { Leeds }}$ & $2 / 2$ & 18.87 & 0.16 & $0 / 2$ & - & - & $2 / 2$ & 19.90 & 0.02 \\
\hline GII.8 & SU25 & $2 / 2$ & 20.88 & 0.06 & $0 / 2$ & - & - & $2 / 2$ & 22.94 & 0.22 \\
\hline GII.10 & $\underline{\text { Erfurt }}$ & $2 / 2$ & 6.70 & 0.05 & $2 / 2$ & 31.22 & 0.30 & $2 / 2$ & 8.73 & 0.16 \\
\hline GII.12 & Pirna & $2 / 2$ & 17.04 & 0.05 & $0 / 2$ & - & - & $2 / 2$ & 19.14 & 0.13 \\
\hline GII.17 & CSE1 & $2 / 2$ & 29.36 & 0.11 & $0 / 2$ & - & - & $2 / 2$ & 32.07 & 0.24 \\
\hline GIIb & $\underline{\mathrm{ND}}$ & $2 / 2$ & 7.04 & 0.12 & $2 / 2$ & 30.19 & 1.32 & $2 / 2$ & 8.74 & 0.02 \\
\hline GIIc & $\underline{\mathrm{ND}}$ & $2 / 2$ & 8.78 & 0.00 & $0 / 2$ & - & - & $2 / 2$ & 10.63 & 0.20 \\
\hline GII? & ND & $2 / 2$ & 30.51 & 0.05 & $0 / 2$ & - & - & $2 / 2$ & 30.69 & 0.05 \\
\hline & ND & $2 / 2$ & 24.12 & 0.08 & $0 / 2$ & - & - & $2 / 2$ & 24.61 & 0.07 \\
\hline & ND & $2 / 2$ & 29.89 & 0.06 & $0 / 2$ & - & - & $2 / 2$ & 29.63 & 0.63 \\
\hline
\end{tabular}

${ }^{a}$ Number of positives/number of tested samples

Underlined: RNA fragments 
Table 4. Sensitivities of assays for detection of NV genogroup II (GII.4, Lorsdale)

\begin{tabular}{|c|c|c|c|c|c|c|c|c|c|c|c|c|c|c|c|}
\hline \multirow{3}{*}{$\begin{array}{l}\text { Titer } \\
\text { (PCRU/ } \\
\text { reaction) }\end{array}$} & \multicolumn{9}{|c|}{ Method A } & \multirow{2}{*}{\multicolumn{3}{|c|}{$\begin{array}{c}\text { Method B } \\
\text { (Generon assay) }\end{array}$}} & \multirow{2}{*}{\multicolumn{3}{|c|}{$\begin{array}{c}\text { Method C } \\
\text { (AnDiaTec assay) }\end{array}$}} \\
\hline & \multicolumn{3}{|c|}{$\begin{array}{l}\text { Platinum kit, } \\
\text { Invitrogen }\end{array}$} & \multicolumn{3}{|c|}{$\begin{array}{c}\text { UltraSense kit, } \\
\text { Invitrogen }\end{array}$} & \multicolumn{3}{|c|}{ AgPath kit, Ambion } & & & & & & \\
\hline & $+/ \mathrm{n}^{\mathrm{a}}$ & $\begin{array}{l}\text { Mean } \\
\text { CP }\end{array}$ & SD & $+/ \mathrm{n}^{\mathrm{a}}$ & $\begin{array}{l}\text { Mean } \\
\text { CP }\end{array}$ & $\mathrm{SD}$ & $+/ \mathrm{n}^{\mathrm{a}}$ & $\begin{array}{l}\text { Mean } \\
\mathrm{CP}\end{array}$ & SD & $+/ \mathrm{n}^{\mathrm{a}}$ & $\begin{array}{l}\text { Mean } \\
\text { CP }\end{array}$ & $\mathrm{SD}$ & $+/ \mathrm{n}^{\mathrm{a}}$ & $\begin{array}{l}\text { Mean } \\
\mathrm{CP}\end{array}$ & SD \\
\hline $2.5 \times 10^{4}$ & $5 / 5$ & 23.79 & 0.13 & $5 / 5$ & 25.43 & 0.10 & $2 / 2$ & 26.04 & 0.03 & $5 / 5$ & 24.32 & 0.25 & $5 / 5$ & 23.50 & 0.15 \\
\hline $2.5 \times 10^{3}$ & $5 / 5$ & 27.29 & 0.12 & $5 / 5$ & 28.93 & 0.07 & $2 / 2$ & 29.52 & 0.07 & $5 / 5$ & 27.89 & 0.14 & $5 / 5$ & 26.87 & 0.14 \\
\hline $2.5 \times 10^{2}$ & $5 / 5$ & 30.31 & 0.11 & $5 / 5$ & 32.10 & 0.17 & $2 / 2$ & 32.54 & 0.09 & $5 / 5$ & 30.84 & 0.47 & $5 / 5$ & 30.19 & 0.05 \\
\hline 25 & $5 / 5$ & 32.86 & 0.18 & $5 / 5$ & 35.17 & 0.79 & $2 / 2$ & 35.68 & 0.75 & $5 / 5$ & 33.31 & 1.34 & $5 / 5$ & 33.09 & 0.15 \\
\hline 2.5 & $5 / 5$ & 34.63 & 0.44 & $2 / 5$ & 36.14 & 1.14 & $0 / 2$ & - & - & $3 / 5$ & 36.14 & 1.14 & $5 / 5$ & 36.21 & 0.53 \\
\hline 0.25 & $4 / 5$ & 34.68 & 0.52 & $0 / 5$ & - & - & $0 / 2$ & - & - & $1 / 5$ & 39.37 & - & $0 / 5$ & - & - \\
\hline
\end{tabular}

${ }^{\mathrm{a}}$ Number of positives/number of tested samples 
Table 3. Sensitivities of Method A for detection of NoV genogroup I (GI.4, Queens Arms) using different kits

\begin{tabular}{|c|c|c|c|c|c|c|c|c|c|}
\hline \multirow{2}{*}{$\begin{array}{l}\text { Titer } \\
\text { (PCRU/ } \\
\text { reaction) }\end{array}$} & \multicolumn{3}{|c|}{$\begin{array}{l}\text { Platinum kit, } \\
\text { Invitrogen }\end{array}$} & \multicolumn{3}{|c|}{ UltraSense kit, Invitrogen } & \multicolumn{3}{|c|}{ AgPath kit, Ambion } \\
\hline & $+/ \mathrm{n}^{\mathrm{a}}$ & $\begin{array}{l}\text { Mean } \\
\mathrm{CP}\end{array}$ & SD & $+/ \mathrm{n}^{\mathrm{a}}$ & $\begin{array}{l}\text { Mean } \\
\mathrm{CP}\end{array}$ & SD & $+/ \mathrm{n}^{\mathrm{a}}$ & $\begin{array}{l}\text { Mean } \\
\mathrm{CP}\end{array}$ & SD \\
\hline $1.68 \times 10^{4}$ & $3 / 3$ & 26.38 & 0.55 & $2 / 2$ & 28.66 & 0.06 & $2 / 2$ & 30.63 & 0.15 \\
\hline $1.68 \times 10^{3}$ & $3 / 3$ & 29.43 & 0.14 & $2 / 2$ & 32.81 & 0.82 & $2 / 2$ & 33.11 & 0.30 \\
\hline $1.68 \times 10^{2}$ & $3 / 3$ & 32.88 & 0.37 & $2 / 2$ & 35.33 & 1.29 & $2 / 2$ & 35.65 & 0.83 \\
\hline 16.8 & $3 / 3$ & 37.32 & 2.33 & $2 / 2$ & 37.47 & 1.48 & $2 / 2$ & $>40.0$ & - \\
\hline 1.68 & $1 / 3$ & $>40.0$ & - & $1 / 2$ & 37.46 & - & $0 / 2$ & - & - \\
\hline 0.16 & $0 / 3$ & - & - & $0 / 2$ & - & - & $0 / 2$ & - & - \\
\hline
\end{tabular}

${ }^{a}$ Number of positives/number of tested samples 